\title{
Performance of Tomato Varieties during Rainy Season under Plastic House Conditions
}

\author{
Tika R. Chapagain, Bhim B. Khatri and Jawahar L. Mandal \\ Nepal Agriculture Research Council, Kathmandu \\ e-mail: chapagaintika@gmail.com
}

\begin{abstract}
Plastic house technology and arrival of hybrid varieties have increased the possibility of tomato cultivation in rainy season in high hills. An experiment was conducted to assess the performance of tomato varieties under plastic house for two consecutive years from 2009 to 2010 at National Commercial Agriculture Research Program (NCARP), Pakhribas (1750m), Nepal. The experiment consisted of eight tomato varieties namely, All Rounder, Bishesh, Dalila, Manisha, Srijna, Suraksha, Trishul and US-04 laid out in a randomized complete block design with three replications. The varieties differed significantly for all observed traits. The highest marketable yield was recorded from All Rounder $\left(86.6 \mathrm{t} \mathrm{ha}^{-1}\right)$ followed by Srijana $\left(80.8 \mathrm{t} \mathrm{ha}^{-1}\right)$. Srijana took the shortest period for flowering and harvesting with an average of 37 and 77 days after transplanting respectively. This was also the tallest variety (268.7 cm) with more clusters (36.23) per plant. However, the highest average single fruit weight was recorded from Manisha (61.94g), and the largest fruit size in US-04 with a diameter of $5.78 \mathrm{~cm}$. Based on yield parameter, the varieties All Rounder and Srijana are recommended for commercial cultivation under plastic house conditions.
\end{abstract}

Key words: tomato, plastic house, rainy season, high hill

\section{Introduction}

Tomato (Lycopersicon esculentum Mill.) is one of the major commercial vegetable crops in Nepal (Ghimire et al. 2001). Though tomato is best suited to the Tarai, in low and mid hills, it is becoming increasingly attractive for cash generation in the high hills also (Pandey \& Chaudhary 2004). Since, tomato supply from Tarai is constrained by high temperature, low fruit set, low flowering, bacterial wilt etc (Pandey et al. 2006), tomato produced from mid June to November months in the hills (400-1800m) fetches higher market price ranging from Rs. 20 to Rs. $35 \mathrm{~kg}^{-1}$ in domestic and external markets (Budhathoki et al. 2004). In the year of 2009/10 total area and production of this crop in Neapl was estimated 15,609 ha and 242,018t, respectively with an average productivity of 15.5 t ha $^{-1}$ (VDD 2010) which is very los as compared to the productivity of the existing hybrid varieties. Cultivation of new hybrid varieties combined with improved technologies, manifold increment in tomato production is possible.

Plastic house technology is one of the viable alternative for quality tomato production in the high hills (Chapagain et al. 2010). Because of low temperature, high rainfall during flowering stage and blight diseases limit tomato cultivation in open field condition in high hills (Pandey \& Chaudhary 2004). Some farmers practice open field tomato production in low hills with the heavy input of fungicides to control late blight disease despite of low yield (CADP 2008). This practice has increased over spraying of fungicides which are eco-unfriendly and create serious health hazards to the human beings. Due to all of these factors, plastic house tomato production technology is getting popularity among the farmers day by day as a new frontier in the eastern high hills of Nepal (Chapagain et al. 2010). 
It is well-known that appropriate varieties under proper management yield high. But varietal studies conducted so far in tomato crop has revealed that the variety suitable for open field condition may not be suitable for plastic house. Most of the tomato varieties set fruit poorly even under plastic house conditions (Budhathoki et al. 2004). Tomato varieties are very sensitive to micro-climatic condition. Due to this reason, those varieties performing better in western region may not be suitable for eastern region. Maximum day and minimum night temperature above $32^{\circ} \mathrm{C}$ and $21^{\circ} \mathrm{C}$ respectively are known to limit fruit set due to an impaired physiological process in flower and fruit setting and or due to abscission (Bhattarai \& Subedi 1996). Therefore, selection of area and technology specific tomato varieties is needed. Srijana, a recently released hybrid and All Rounder, another the most popular variety in the eastern hills had to be further evaluated under plastic house conditions in eastern region. Thus, this study aimed to identify suitable varieties of tomato under plastic house condition for eastern high hills of Nepal.

\section{Methodology}

The experiment was conducted at the National Commercial Agriculture Research Programme, Pakhribas (1750 m), Nepal, in a randomized complete block design (RCBD) for two consecutive years from 2009 and 2010 under plasitic house with three replications. Eight tomato hybrids namely, Srijana developed at National Agricultural Research Council, Nepal), All Rounder (a popular tomato variety of eastern region), Manisha, US-04, Surakhsa, Bishesh and Trishul (Indian hybrids) and Dalila (Thailand) were evaluated for their earliness and yield characteristics. The individual plot size was $4.5 \mathrm{~m}^{2}$ which accommodated 12 plants per plot where row to row spacing was $75 \mathrm{~cm}$ and plant to plant spacing $50 \mathrm{~cm}$ was maintained. The size of plastic house was $7 \mathrm{~m}$ wide and $18 \mathrm{~m}$ long with $3 \mathrm{~m}$ height at the center and $1.5 \mathrm{~m}$ at the side pole. Common white polyethylene sheet with 200 gauges was used as roofing material. All of these varieties were seeded in the nursery bed in last week of the April and almost four weeks old seedlings were transplanted in the experimental plots in last week of May in both the years. Compost at the rate of 30 tons and NPK 75:100:100 $\mathrm{kg} \mathrm{ha}^{-1}$ were applied as basal dose during field preparation and additional dose of nitrogen $75 \mathrm{~kg} \mathrm{ha}^{-1}$ was applied as top dressing at 30 days after transplanting. In addition, Vegimix, a natural commercially available plant food supplement was applied at the rate of $2.5 \mathrm{ml}$ per 20 liters of water at monthly intervals after transplanting. Irrigation was done as and when necessary. After two subsequent harvests urea was applied at the rate $5 \mathrm{gm}$ per plant till the final harvest. The observations on days to flowering and harvest, number of clusters per plant, fruit diameter, average fruit weight, plant height and marketable fruit yield were recorded.

Diseases and insects were observed regularly. Percentage leaf damage by late blight (Phytophthora infestans) disease and leaf miner flies (Bedellia somnulentella Zeller) was recorded. Fungicide Kryloxyl (Metalaxyl 8\% and Mancozeb 64\% were) was sprayed at the rate of $2 \mathrm{~g}$ liter ${ }^{-1}$ at 15 days interval after first observation of late blight disease. Rogor (Dimethoate 30\% EC) was sprayed at the rate of $1 \mathrm{ml}$ liter $^{-1}$ twice during the cropping season to control the leaf miner and fruit borer. Servo Agrospray (Mineral Oil) was sprayed twice at the rate of $10 \mathrm{ml} \mathrm{liter}^{-1}$ to control powdery mildew during the cropping season.

Analysis of variance (ANOVA) was computed to determine the significance level among the treatments using Genstat Discovery Edition 3 (Genstat 2007) software. The significance of differences among treatment means were tested using Duncan's Multiple Range Test (DMRT) through MSTAT computer software (MSTAT 1990).

\section{Results and Discussion Vegetative and flowering characteristics}

Plant height is considered as an important trait in tomato cultivation from management aspect. In this study, tomato varieties differed significantly for this trait at final harvest. Srijana was the tallest $(268.7 \mathrm{~cm})$ variety followed by Manisha $(232.3 \mathrm{~cm})$, whereas, Suraksha was the most dwarf $(113.2 \mathrm{~cm})$ variety which was at par with Bishesh $(122.4 \mathrm{~cm})$. Tall varieties need almost double staking materials than that of dwarf varieties. Staking materials covers about $10 \%$ of overall production cost (CADP 2008). Furthermore, the labor cost associated with staking is also increased.

Days to flowering and harvest are very important attributes to determine the earliness which is very 
Tika R. Chapagain et al./Performance of Tomato........

crucial from marketing perspective. The difference among the varieties on days to flowering and harvest from transplanting was highly significant (Table 1). Srijana took the shortest period (31 days) for flowering and harvesting (77 days) while Bishesh took the longest days for flowering (34 days). Only six days difference was noticed among the varieties for harvesting, however, the single day is crucial from marketing perspective in perishable vegetable crops. Paudel et al. (2004) reported that Manisha and Suraksha took 66 and 67 days respectively for the first harvest after transplanting in western mid hill condition (1000m). Bhattarai and Subedi (1996) reported the flowering days of different varieties ranged from 53 to 74 days after transplanting in open field condition. Pandey et al. (2006) has reported 35 to 40 days for different varieties in plastic house condition which is almost similar to this study. They further reported that variety NSITH-162 took the shortest period (66 days) from transplanting to first harvest, whereas, variety Avinash-2 and BL-410 took the longest period (71 days). The differences among the tested varieties may be attributed to their genetic diversity, whereas, the differences with earlier research in other parts of the country could be due to the differences in varieties, management and growing conditions. The study revealed that the existing varieties take almost 80 days from transplanting to the first harvest in eastern high hill conditions, therefore to fetch the premium price in the market at right time, early varieties are necessary. Likewise, from June to December farmers get offseason price in eastern region (CADP 2008). Therefore selection of early varieties and early planting is recommended for commercial cultivation.

Table 1. Mean values for plant height $(\mathrm{cm})$, days to flowering and days to harvest of tomato varieties under plastic house at Pakhribas during the years 2009 and 2010

\begin{tabular}{|c|c|c|c|c|c|c|c|c|c|}
\hline \multirow{2}{*}{$\begin{array}{l}\text { Tomato } \\
\text { varieties }\end{array}$} & \multicolumn{3}{|c|}{ Plant height (cm) at final harvest } & \multicolumn{3}{|c|}{ Days to first flowering } & \multicolumn{3}{|c|}{ Days to first harvest } \\
\hline & 2009 & 2010 & Mean & 2009 & 2010 & Mean & 2009 & 2010 & Mean \\
\hline All Rounder & $117.9 \mathrm{f} \dagger$ & $132.8 \mathrm{ef}$ & 125.3ef & $28.33 b$ & $35.33 b c$ & $31.83 b c$ & $80.33 a$ & 84.00 & $82.17 \mathrm{a}$ \\
\hline Bishesh & $116.8 \mathrm{f}$ & $127.9 \mathrm{f}$ & $122.4 \mathrm{fg}$ & $30.00 \mathrm{a}$ & 38.33a & $34.17 \mathrm{a}$ & $78.00 \mathrm{ab}$ & $82.67 a$ & 80.33ab \\
\hline Dalila & $162.7 \mathrm{c}$ & $187.0 \mathrm{c}$ & $174.8 \mathrm{c}$ & $28.00 \mathrm{~b}$ & 34.33cd & $31.17 b c$ & $79.00 \mathrm{a}$ & $79.00 c$ & $79.00 \mathrm{bc}$ \\
\hline Manisha & $221.6 b$ & $243.0 \mathrm{~b}$ & $232.3 b$ & 29.00ab & $35.67 \mathrm{~b}$ & $32.33 \mathrm{~b}$ & $75.67 \mathrm{bc}$ & 82.67ab & $79.17 b c$ \\
\hline Srijana & $253.3 a$ & $284.0 \mathrm{a}$ & $268.7 \mathrm{a}$ & $27.67 \mathrm{~b}$ & $33.67 d$ & $30.67 \mathrm{c}$ & $74.00 \mathrm{c}$ & $79.00 \mathrm{c}$ & $76.50 \mathrm{c}$ \\
\hline Suraksha & $110.2 \mathrm{f}$ & $116.1 \mathrm{~g}$ & $113.2 \mathrm{~g}$ & $28.33 b$ & 33.67d & $31.00 \mathrm{bc}$ & $78.67 a$ & $80.67 \mathrm{bc}$ & 79.67ab \\
\hline Trishul & $128.5 \mathrm{e}$ & $140.3 \mathrm{e}$ & $134.4 \mathrm{e}$ & $28.33 b$ & $34.67 \mathrm{bcd}$ & $31.50 \mathrm{bc}$ & $75.67 \mathrm{bc}$ & $80.67 \mathrm{bc}$ & $78.17 \mathrm{bc}$ \\
\hline US-04 & $143.2 \mathrm{~d}$ & $151.3 d$ & $147.2 d$ & $28.67 b$ & 34.33cd & $31.50 \mathrm{bc}$ & $74.00 \mathrm{c}$ & 81.33bc & $77.67 \mathrm{bc}$ \\
\hline F-test & $<.001$ & & & $<.001$ & & & $<.01$ & & \\
\hline LSD (0.05) & 9.291 & & & 1.230 & & & 2.454 & & \\
\hline CV (\%) & 4.8 & & & 3.3 & & & 2.6 & & \\
\hline
\end{tabular}

$\dagger$ Mean of 3 replications. In the columns means followed by the same letter are not significantly different $(p<0.05)$ by DMRT.

\section{Yield characteristics}

Number of fruit clusters per plant and weight of individual fruit are major determinants of yield in tomato.The difference among the varieties on number of clusters per plant, average fruit weight and average fruit diameter was highly significant (Table 2). The highest number of clusters were recorded from Srijana (36.23) followed by Dalila (30.10), whereas Suraksha gave the lowest number of clusters per plant. In western hills, this trait was found ranging14.8 to 38.4 in plastic house conditions among tomato varieties tested (Pandey et al. 2006). The results of this study also fall within this range. It is one of the major criteria to select better variety for its higher yield and preferable fruit size. The number of clusters directly influenced the fruit yield. However, fruit size and fruit number per cluster are also determining factors (Pandey et al. 2006). Fruits of the US-04 were largest $(5.78 \mathrm{~cm})$ among the tested varieties, however, average fruit weight was higher in Manisha (61.94gm). The smallest fruit diameter $(4.04 \mathrm{~cm})$ was recorded from Dalila which also had the lowest fruit weight (34.73gm). Budhathoki (2006) had reported higher average fruit weight of these varieties in Kathmandu condition. The difference can be attributed to different growing environment. 
Nepal Journal of Science and Technology 12 (2011) 17-22

Table 2. Mean values for number of clusters per plant, average fruit weight (g) and fruit diameter (cm) of tomato varieties under plastic house at Pakhribas during the years 2009 and 2010

\begin{tabular}{|c|c|c|c|c|c|c|c|c|c|}
\hline \multirow{2}{*}{$\begin{array}{l}\text { Tomato } \\
\text { varieties }\end{array}$} & \multicolumn{3}{|c|}{ Number of cluster per plant } & \multicolumn{3}{|c|}{ Average fruit wt (g) } & \multicolumn{3}{|c|}{ Average fruit diameter $(\mathrm{cm})$} \\
\hline & 2009 & 2010 & Mean & 2009 & 2010 & Mean & 2009 & 2010 & Mean \\
\hline All Rounder & $31.27 \mathrm{~b} \dagger$ & $27.47 \mathrm{bc}$ & $29.37 b$ & $54.24 \mathrm{~b}$ & $52.40 c$ & 53.32 & $4.91 \mathrm{c}$ & $4.68 \mathrm{~d}$ & $\overline{4.80 \mathrm{~cd}}$ \\
\hline Bishesh & 24.67d & 20.93d & $22.80 d$ & $54.82 \mathrm{~b}$ & $50.40 \mathrm{~cd}$ & $52.61 b$ & $5.04 \mathrm{bc}$ & $4.78 \mathrm{~d}$ & 4.91cd \\
\hline Dalila & $27.33 c$ & $32.87 \mathrm{a}$ & 30.10b & $30.57 \mathrm{e}$ & $38.89 \mathrm{e}$ & 34.73d & $3.91 d$ & $4.18 \mathrm{e}$ & $4.04 \mathrm{e}$ \\
\hline Manisha & 29.73b & $28.80 \mathrm{~b}$ & $29.27 b$ & $65.47 \mathrm{a}$ & $58.41 \mathrm{ab}$ & $61.94 a$ & $5.06 \mathrm{bc}$ & $5.18 \mathrm{c}$ & $5.12 b c$ \\
\hline Srijana & $39.00 \mathrm{a}$ & $33.47 \mathrm{a}$ & 36.23a & $48.07 \mathrm{~cd}$ & 46.67d & $47.34 \mathrm{c}$ & $4.74 \mathrm{c}$ & 4.51de & 4.63d \\
\hline Suraksha & $15.80 \mathrm{f}$ & $18.67 \mathrm{e}$ & $17.23 f$ & 49.40d & $61.67 \mathrm{a}$ & $55.53 b$ & $5.45 \mathrm{a}$ & $5.63 b$ & $5.54 a$ \\
\hline Trishul & 23.00d & $26.73 c$ & $24.87 \mathrm{c}$ & 46.34d & $57.22 \mathrm{~b}$ & 51.78ab & $5.40 \mathrm{ab}$ & $5.43 \mathrm{bc}$ & 5.41ab \\
\hline US-04 & $19.03 e$ & $22.20 \mathrm{~d}$ & $20.62 \mathrm{e}$ & $50.93 \mathrm{bc}$ & 59.89ab & 55.91 & $5.52 \mathrm{a}$ & $6.03 a$ & 5.78a \\
\hline F-test & $<.001$ & & & $<.001$ & & & $<.001$ & & \\
\hline LSD (0.05) & 2.364 & & & 3.563 & & & 0.340 & & \\
\hline CV (\%) & 7.6 & & & 5.9 & & & 7.0 & & \\
\hline
\end{tabular}

$\dagger$ Mean of 3 replications. In the columns means followed by the same letter are not significantly different $(p<0.05)$ by DMRT.

\section{Marketable fruit yield}

Marketable fruit yield is the major determinant character while selecting a particular variety for commercial cultivation. The difference among the varieties on marketable fruit yield was highly significant (Fig.1). All Rounder produced the highest marketable fruit yield $\left(87.53 \mathrm{t} \mathrm{ha}^{-1}\right)$ in 2009 and $82.1 \mathrm{t}$ ha $^{-1}$ in 2010 with the mean of 86.5 t ha $^{-1}$ yield. Likewise, Srijana produced $82.8 \mathrm{t} \mathrm{ha}^{-1}$ in 2009 and $78.8 \mathrm{t} \mathrm{ha}^{-1}$ in 2010 with the mean of $80.8 \mathrm{tha}^{-1}$ yield which was at par with All Rounder. Chapagain et al. (2010) reported 47.9 $\mathrm{t} \mathrm{ha}^{-1}$ and $30.9 \mathrm{t} \mathrm{ha}^{-1}$ fruit yield in plastic house and in open field condition respectively in the farmers' field of ARS Pakhriabas. The higher yield obtained at onstation conditions could be due to the good management practices. Pandey et al. (2006) reported that almost similar trend of tomato fruit yield in western hills of Nepal. The yield obtained from this study is very high as compared to national and regional productivity of tomato (VDD 2009, CADP 2008). Many folds increase in fruit yield might be due to the variety growing condition in plastic house. However, the yield obtained from this study is lower as compared to the yield reported by Budhathoki et al. (2004) in Kathmandu condition.

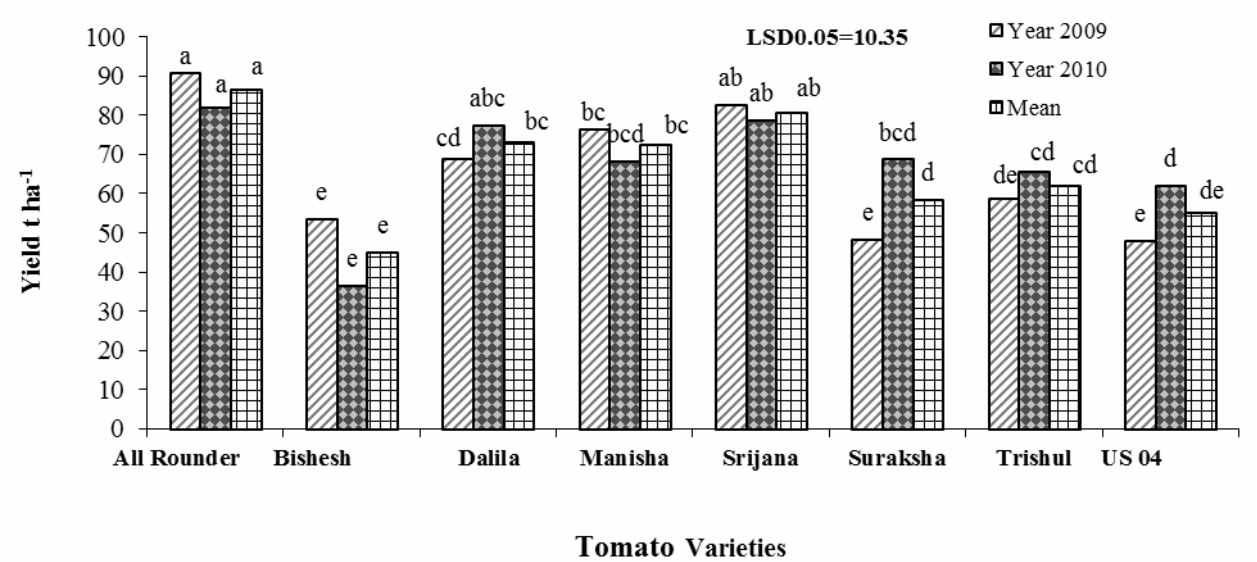

Fig. 1. Mean values for marketable fruit yield $\left(\mathrm{t} \mathrm{ha}^{-1}\right)$ of tomato varieties under plastic house at Pakhribas, during the years 2009 and 2010. In the figure same letters are not significantly different by DMRT at $P=0.05$ 
Tika R. Chapagain et al./Performance of Tomato.......

\section{Diseases and insects}

Diseases and insect pests are major threats of tomato crop. Effects of late blight (P. infestans) on tomato varieties differed significantly (Fig. 2).

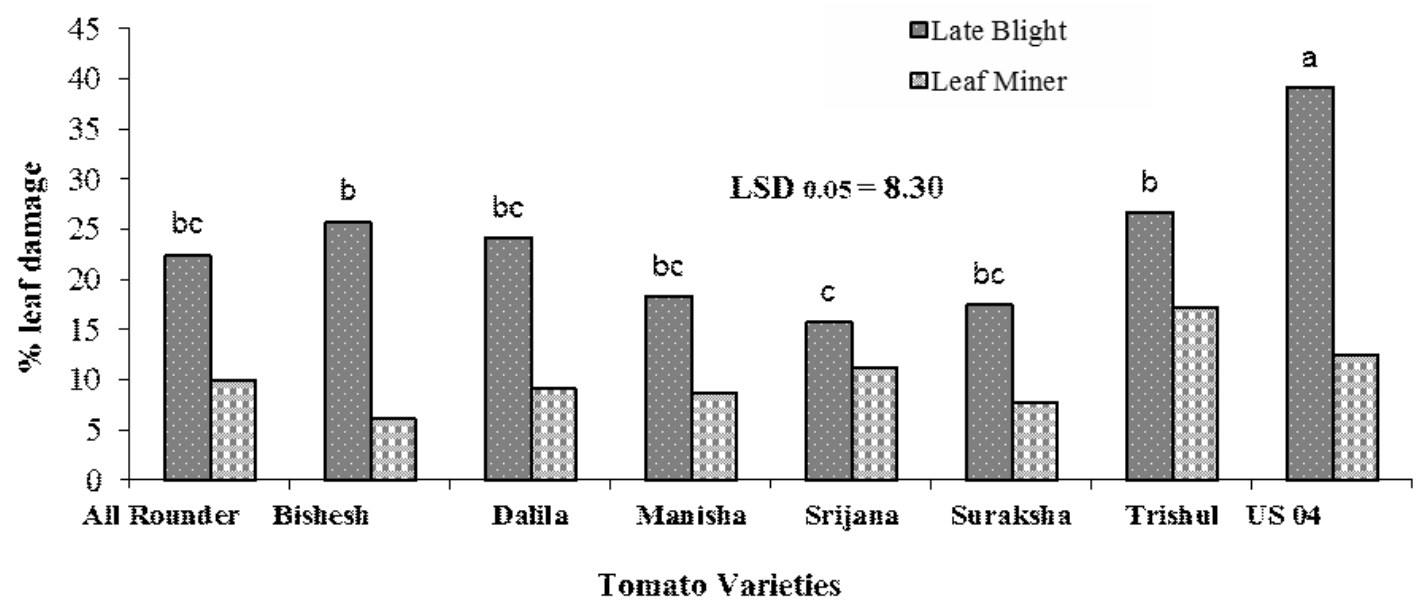

Fig. 2. Mean values for \% leaf affected by leaf miner flies and late blight disease in tomato varieties under plastic house conditions at Pakhribas, during the years 2009 and 2010. In the figure same letters are not significantly different by DMRT at $P=0.05$

The highest late blight damage was observed on US04 and the lowest on Srijana, however, the effect on yield was not significant. The covariate analysis of late blight and leaf miner flies both also showed nonsignificant effect on yield. Symptoms of early blight and powdery mildew were also observed. The infestation of leaf miner among the varieties was nonsignificant. Besides leaf miner, fruit borer and fruit flies also were noticed on tomato.

The results showed that Srijana was the earliest variety for flowering, fruiting and harvesting. The highest yield obtained from All Rounder which was at par with Srijana indicated that both these varieties are suitable for plastic house cultivation. Further research on variety selection, nutrient, disease and insect management (mainly leaf miner fly) is necessary to increase the productivity of tomato under plastic house conditions. Since durable plastic called Cilpaulin is becoming very popular among the tomato growers, thickness requirement of roofing material has also to be verified. Research on cropping pattern is also important to maximize the return and utilize the interrow space between tomato crops.

\section{Acknowledgements}

We thank B. P. Chaudhary and R. K. Shah for their support during data collection. Thanks are also offered to Mr. R. N. Chaudhary for his constant support during the study. This research was conducted under the financial support of Nepal Agriculture Research Council (NARC), Nepal.

\section{References}

Bhattarai, S. P. and P. P. Subedi. 1996. Heat and bacterial wilt tolerant tomato varietal evaluation during 1992/ 93- 1994/95 season. LARC Working Paper No. 96/56. Lumle Agriculture Research Centre, Kaski, Nepal.

Budhathoki, K. 2006. Market oriented organic and offseason vegetable cultivation technology. National Agriculture and Forestry Private Limited, $\mathrm{Na}$ Tole, Lalitpur, Nepal, 111pp.

Budhathoki, K., N. G. Pradhan, H. N. Regmi and P. R. Bhurtyal. 2004. Evaluation of tomato cultivars for offseason production under polyhouse and open field condition. In: Proceedings of the Fourth National Horticultural Research Workshop (March 2-4, 2004), Kathmandu (Eds. B.B. Khatri, B.P. Sharma, P.P. Khatiwada, K.P. Paudyal, B.R. Khadge and H.N. Regmi). Horticulture Research Division, National Agriculture Research Council, Kathmandu, pp. 413-418. 
CADP. 2008. Final value chain report of tomato. Commercial Agriculture Development Project. Ministry of Agriculture and Cooperaives, Biratnagar, Nepal. www.cadp.gov.np/Documents_Uplaods/ Reports.

Chapagain, T. R., S. Piya, J. L. Mandal and B.P. Chaudhary. 2010. Up-scaling of polyhouse tomato production technology in mid and high hills of eastern Nepal. In: Proceedings of ninth national outreach research workshop (June 7-8, 2010), Kathmandu (Eds. M. N. Paudel, T. P. Barakoti and Y. N. Ghimire). Outreach Research Division, Nepal Agriculture Research Council, Kathmandu. pp. 116-120.

Genstat. 2007. Genstat for windows. Discovery edition 3. Lawes Agricultural Trust, Rothamsted Experimental Station, U.K.

Ghimire, S. R., P. P. Subedi and S. K. Green. 2001. Status of tomato yellow leaf curl virus in tomato in the western hills of Nepal. Nepal Agriculture Research Journal 5: 1-4. www.nepjol.info/index.php/NARJ/ article/download/4856/4027.pdf

MSTATC. 1990. A Microcomputer program for the design, management, and analysis of agronomic research experiments. Michigan State Univ., East Lansing, USA.
Pandey, Y. R., A. B. Pun and K. P. Upadhyay. 2006. Participatory varietal evaluation of rainy season tomato under plastic house condition Nepal Agriculture Research Journal 7:11-15.

Pandey, Y. R. and B. N. Chaudhary. 2004. Evaluation of tomato varieties and their planting dates for commercial production under Jumla agro-ecological condition. In: Proceedings of the Fourth National Horticultural Research Workshop (March 2-4, 2004), Kathmandu (Eds. B.B. Khatri, B.P. Sharma, P.P. Khatiwada, K.P. Paudyal, B.R. Khadge and H.N. Regmi). Horticulture Research Division, Nepal Agriculture Research Council, Kathmandu, pp. 380385.

Paudel, K. B., I. P. Gautum, H. N. Regmi, J. N. Chaudhary, K. P. Upadhya, P. Dauwadi, D. Pokhrel and B. Khatri. 2004. Evaluation of tomato genotypes in farmers' field for rainy season in the western hills of Nepal. In: Proceedings of the fourth national horticultural research workshop (March 2-4, 2004), Kathmandu (Eds. B.B. Khatri, B.P. Sharma, P.P. Khatiwada, K.P. Paudyal, B.R. Khadge and H.N. Regmi). Horticulture Research Division-NARC, Kathmandu, pp. 422-426. VDD. 2010. Annual progress report (2065/2066). Vegetable Development Directorate, Agriculture Department, Ministry of Agriculture and Coperative, Nepal.89pp. 